\title{
Evaluation of Surface Roughness and Streptococcus mutans Adhesion to Bulk-Fill Resin Composites Polished with Different Systems
}

\author{
Wafaa E. Soliman', Ashraf I. Ali'², Walid F. Elkhatib ${ }^{3,4^{*}}$ \\ ${ }^{1}$ Department of Microbiology and Biotechnology, Faculty of Pharmacy, Delta University for Science and Technology, Cairo, Egypt \\ ${ }^{2}$ Faculty of Dentistry, Mansoura University, Mansoura, Egypt \\ ${ }^{3}$ Department of Microbiology and Immunology, Faculty of Pharmacy, Ain Shams University, African Union Organization St., \\ Cairo, Egypt \\ ${ }^{4}$ Department of Microbiology and Immunology, School of Pharmacy \& Pharmaceutical Industries, Badr University in Cairo \\ (BUC), Cairo, Egypt \\ Email: *walid-elkhatib@pharma.asu.edu.eg
}

How to cite this paper: Soliman, W.E., Ali, A.I. and Elkhatib, W.F. (2019) Evaluation of Surface Roughness and Streptococcus mutans Adhesion to Bulk-Fill Resin Composites Polished with Different Systems. Advances in Microbiology, 9, 87-101. https://doi.org/10.4236/aim.2019.91007

Received: December 2, 2018

Accepted: January 21, 2019

Published: January 24, 2019

Copyright $\odot 2019$ by author(s) and Scientific Research Publishing Inc. This work is licensed under the Creative Commons Attribution International License (CC BY 4.0).

http://creativecommons.org/licenses/by/4.0/

\begin{abstract}
Purpose: Bacterial adhesion represents the initial step in biofilm formation, dental caries and decay. This study aimed to evaluate and compare surface roughness and bacterial adhesion to bulk fill resin composites polished with different systems. Methods: Filtek Z350 XT (Incremental-fill resin composite), Filtek Bulk-fill Posterior (Bulk-fill resin composite), and Tetric N Ceram (Bulk-fill resin composite) were used as resin composites. The polishing systems used in this study were Sof-Lex multi-step, PoGo one step, and Mylar strip. Scanning electron microscope (SEM) was used to examine the surface roughness and adhesion of Streptococcus mutans ATCC 25175 standard strain to bulk-fill resin composites. Results: The type of restorative materials did not affect the surface roughness or bacterial adhesion $(\mathrm{p}>0.05)$ but the polishing systems were significant $(\mathrm{p}<0.05)$ influencing factors. Furthermore, Pearson correlation revealed a statistically significant $(\mathrm{p}<0.001)$ association $(R=0.943)$ between surface roughness and bacterial adhesion to the tested surfaces. Conclusion: Regardless of the restorative material, Mylar polishing system revealed the smoothest surface and the lowest adhesion of $S$. mutans as compared to Pogo one step and Sof-Lex multi-step polishing systems.
\end{abstract}

\section{Keywords}

Bacterial Adhesion, Surface Roughness, Streptococcus mutans, 
Polishing Systems

\section{Introduction}

Oral biofilm is formed of miscellaneous microbes found on the tooth surface, and enclosed in a matrix of polymers of bacterial and salivary origin. The main causes for restoration replacement are dental surface biodegradation, secondary caries, and periodontal inflammation associated with oral biofilm formation. The initial and critical step of plaque formation includes adhesion of bacteria known as early colonizers such as oral streptococci [1] [2]. These bacteria bind to various proteins including alpha-amylase, proline-rich proteins, and glycoprotein [3]. Oral biofilm formation was influenced by many factors such as surface roughness and surface free energy [4] [5]. The adhesion and initial colonizing of bacteria along cracks and pits in enamel were shown by microscopic examination of early plaque formation, indicating the influence of surface structure on bacterial adhesion [2]. The increasing demands for tooth-colored restorations and seek for amalgam replacements have strong association with enlarged requests for direct tooth-colored restorative materials. Within the past few years this esthetic look of tooth-colored restorations is of large significance to each the dentist and patient [6].

One of the predictable disadvantages of dental composites is its polymerization shrinkage. In the event that occurs while the resin composite materials are inside the cavity bonded to its walls, stresses may develop inside resin composite. Consequently, debolding, postoperative sensitivity, marginal staining, recurrent caries, and 8 cuspal deflections may develop and induce smaller scale breaks as well as cusp cracks [7]. Incremental composites application technique is anticipated to decrease the $\mathrm{C}$-factor, enabling a specific amount of flow to reduce the shrinkage stress partially [8]; on the other hand, it has number of impediments, for example, entrapment of voids between the increments, bond failure between the increments and the long time required to cure each increment separately [9] [10].

Novel restorative materials have been introduced to solve many of the problems associated with the incremental method of employing resin that are used as bulk fill composites. Bulk-fill resin-based composites carry the advantages of improving polymerization depth, and diminishing polymerization shrinkage stresses and cuspal deflection rates, as well as shortening the time of incremental layering techniques [11]. Appropriate finishing and polishing of dental restorations is required for oral health protection. A rough composite resin surface may decrease the shine and esthetic appearance. Moreover, it raises the number of sites on the restoration surface prone to bacterial biofilm accumulation, which results in increasing risk of both caries and periodontal inflammation [12] [13]. Generally, the finished/polished or surface sealant-coated composite resins have low susceptibility to adhere to oral microorganisms [14]. 
Surface roughness has effects on recoloring and bacterial attachment to the restoration. Accordingly, many strategies for finishing and polishing of toothcolored restoratives have been developed. Recently, specialists have implemented different trials to accomplish a high surface quality by applying one-step polishing systems [15]. It has been demonstrated that, the outcomes of one-step strategy are better or possibly practically identical to multi-step procedures and may be item related [16] [17]. Concurrently in view of the most recent technology, it is hard to acquire all around well-polished restorations even when utilizing appropriate restorative materials and the best polishing system may act as a predisposing factor for biofilm formation [18].

Salivary pellicles quickly coat every uncovered surface in the mouth. Pellicle arrangement is trailed by the grip of facultative anaerobic pioneer bacteria [19], for example, Streptococcus gordonii, Streptococcus oralis, and Streptococcus sanguine [20]. Early colonizing microbes play a crucial role in the consequent adhesion of cariogenic bacteria, such as Streptococcus mutans. Substratum surface roughness $(\mathrm{Ra})$ and surface free energy are supposed to be as the primary variables influencing dental plaque formation [21]. Bacterial plaque formation and secondary caries are caused by buildup of bacteria on the marginal areas of enamel and restorative material [4]. The main reason of replacement is caries formation around dental restorations which require efforts to decrease or avert plaque formation on restorative materials [22]. Multiple in vitro and in vivo models have examined both the adhesion of a variety of microorganisms to dental restorations and the mechanisms involved in [23] [24].

The outcome of diverse finishing/polishing systems on surface roughness and bacterial adhesion of composite resins has been reported in the literature [25] [26]. Nevertheless, little data about the bacterial adhesion to bulk-fill resin composites are available in the literature. In this context, the current study aimed to compare and evaluate surface roughness and adhesion of Streptococcus mutans to bulk-fill resin composites with different polishing systems.

\section{Materials and Methods}

\subsection{Materials}

Filtek Z350 XT (Incremental-fill resin composite), Filtek Bulk-fill Posterior (Bulk-fill resin composite), and Tetric N Ceram (Bulk-fill resin composite) were used as resin composites in this study (Table 1).

The finishing/polishing systems (F/P) used in this study were Sof-Lex Pop-on Discs Multi-step, PoGo One step, and Mylar strip. The composition and manufacturers of different polishing systems are summarized in Table 2. Streptococcus mutans ATCC 25175 (S. mutans ATCC 25175) standard strain is used in all bacterial adhesion experiments.

\subsection{Methods}

\subsubsection{Specimen Preparation}

A total of 90 standardized specimens, 30 specimens of each restorative material, 
Table 1. Resin composites used in this study.

\begin{tabular}{|c|c|c|c|}
\hline Resin composite & Manufacturer & Composition & Filler load \\
\hline $\begin{array}{l}\text { Filtek Z350 XT } \\
\text { (Incremental-fill } \\
\text { resin composite) }\end{array}$ & $\begin{array}{c}\text { 3M ESPE, St. Paul, } \\
\text { MN, USA }\end{array}$ & $\begin{array}{l}\text { Matrix } \\
\text { Bis-GMA, UDMA, TEGDMA, } \\
\text { PEGDMA, Bis-EMA } \\
\text { Filler } \\
20 \mathrm{~nm} \text { silica filler, } 4 \text { to } 11 \mathrm{~nm} \\
\text { zirconia filler, zirconia/silica } \\
\text { cluster filler }(0.6 \text { to } 10 \mu \mathrm{m})\end{array}$ & $\begin{array}{c}63.3 \text { vol } \% \\
78.5 \text { wt } \%\end{array}$ \\
\hline $\begin{array}{l}\text { Filtek Bulk-fill } \\
\text { Posterior (Bulk-fill } \\
\text { resin composite) }\end{array}$ & $\begin{array}{c}\text { 3M ESPE, St. Paul, } \\
\text { MN, USA }\end{array}$ & $\begin{array}{l}\text { Matrix } \\
\text { Aromatic UDMA, UDMA, } \\
\text { ERGP-DMA, } \\
\text { Diurethane-DMA and } \\
\text { 1,2-dodecane-DMA } \\
\text { Filler } \\
\text { Non-agglomerated/non } \\
\text { aggregated } 20 \mathrm{~nm} \text { filler, non } \\
\text { agglomerated/non aggregated } \\
\text { 4_11 zirconia filler, aggregated } \\
\text { zirconia/silica cluster filler and } \\
\text { a ytterbium trifloride filler }\end{array}$ & $\begin{array}{l}58.4 \text { vol } \% \\
76.5 \text { wt } \%\end{array}$ \\
\hline $\begin{array}{c}\text { Tetic N Ceram } \\
\text { (Bulk-fill resin } \\
\text { composite) }\end{array}$ & $\begin{array}{l}\text { Ivoclar Vivadent, AG, } \\
\text { Schaan, Liechtenstein }\end{array}$ & $\begin{array}{l}\text { Matrix } \\
\text { Dimethacrylates } \\
\text { Filler } \\
\text { Barrium glass, ytterbium } \\
\text { trifluoride, mixed oxides, } \\
\text { polymer fillers }\end{array}$ & $\begin{array}{c}54 \text { vol } \% \\
75-77 \\
\text { wt } \%\end{array}$ \\
\hline
\end{tabular}

Table 2. Polishing systems used in this study.

\begin{tabular}{ccc}
\hline $\begin{array}{c}\text { Polishing } \\
\text { systems }\end{array}$ & Composition & Manufacturer \\
\hline $\begin{array}{c}\text { Sof-Lex Pop-On } \\
\text { Discs } \\
\text { Multi-step }\end{array}$ & $\begin{array}{c}\text { Medium aluminum oxide disc }(40 \mu \mathrm{m}) \\
\text { Fine aluminum oxide disc }(24 \mu \mathrm{m}) \\
\text { Ultra-fine aluminum oxide disc }(8 \mu \mathrm{m})\end{array}$ & $\begin{array}{c}\text { 3M Dental products, St Paul, } \\
\text { MN, USA }\end{array}$ \\
$\begin{array}{c}\text { PoGo } \\
\text { One step }\end{array}$ & Diamond coated micro-polisher & $\begin{array}{c}\text { Dentsuply/Caulk, Milford DE, } \\
\text { USA }\end{array}$ \\
Mylar & polyethylene terephthalate matrix & SS White, Philadelphia, PA, USA \\
Matrix only & & \\
\hline
\end{tabular}

were fabricated using a cylindrical plastic mold $(10 \mathrm{~mm}$ diameter $\times 2 \mathrm{~mm}$ depth). The specimens were prepared by standardized method by applying the mold above a glass slap covered with Mylar strip (SS White, Philadelphia, PA, USA), followed by injecting the restorative material into the mold, covering it again with Mylar strip, and placing a glass slide on top. The material was then pressed between both glass slides to extrude excess material and to reduce voids at the surface. Specimens were cured for 40 seconds with a LED light curing unit through the glass slide and Mylar strip on the top of the specimens once being 
pressed. The light intensity was measured at $800 \mathrm{~mW} / \mathrm{cm}^{2}$. Additional 20 seconds curing on both sides of the specimens was done after removing the stripes and glasses. The resulting specimen's extraneous flanges were removed. All specimens were stored in distilled water at $37^{\circ} \mathrm{C}$ for $24 \mathrm{~h}$ in the incubator until usage [27].

\subsubsection{Surface Roughness}

To evaluate surface roughness, the tested materials are categorized into the following groups; Group 1: These specimens were kept without F/P after removal of Mylar strip to act as control group (30 specimens; ten of each restorative material). After that, the outermost surface of the remaining 60 specimens were surfaced with the super-fine grit finishing diamond bur $(25 \mu \mathrm{m}$, No. 837 KREF.314.014, Brasseler) attached to high speed hand piece (W\&H, RC-90RM, Austria) for 30 seconds at 200,000 rpm. Group 2: Thirty specimens (ten of each restorative material the specimens) were polished with flat broad surface of the Pogo diamond micro polisher disc for 40 seconds, one-step system according to manufacturer's instructions. Group 3: Thirty specimens (ten of each restorative material, the specimens) were polished with three step Sof-Lex aluminum oxide disc system according to manufacturer's instructions. After each polishing step, all the specimens were thoroughly rinsed with water for 10 seconds to remove debris and air-dried for 5 seconds. After completing polishing procedures, specimens were rinsed, cleaned in an ultrasonic cleaner for $3 \mathrm{~min}$, and air dried [28].

\subsubsection{Surface Roughness Measurement}

All the 90 specimens were assessed for surface roughness by using FEI Quanta 200 FEG ESEM (FEI Co., Hillsboro, OR, USA) combined with image analysis to provide both qualitative and quantitative assessments of surface roughness [28].

\subsubsection{Bacterial Adhesion Assay}

Samples used for testing surface roughness were used for assessing bacterial adhesion with the same grouping. Sterilization of each specimen after packing in dry plastic bag in an autoclave at $121^{\circ} \mathrm{C}$ before tested with bacteria. Standard strain of $S$. mutans ATCC 25175 was used for the in vitro adhesion assay. The standard strain was cultured on blood agar and incubated at $37^{\circ} \mathrm{C}$ for $24 \mathrm{~h}$. The colony count was adjusted to $1 \times 10^{6} \mathrm{CFU} / \mathrm{mL}$ from $0.5 \mathrm{McFarland}\left(1.5 \times 10^{8}\right.$ $\mathrm{CFU} / \mathrm{mL}$ ) equivalence turbidity standard (Thermo Scientific ${ }^{\mathrm{mi}}$ Remel, Waltham, MA, USA). In sterile 12-Well Corning microplates (Corning, NY, USA), $2 \mathrm{ml}$ of Muller Hinton $(\mathrm{MH})$ broth culture $\left(1 \times 10^{6} \mathrm{CFU} / \mathrm{mL}\right)$ of $S$. mutans ATCC 25175 were aseptically transferred to each well. The disk materials were then aseptically transferred to the 12-Well Corning microplates (one/well) using sterile forceps and the plates were incubated at $37^{\circ} \mathrm{C}$ for $4 \mathrm{~h}$. After incubation, the disk materials were carefully washed thrice with sterile isotonic saline solution $(0.9 \% \mathrm{w} / \mathrm{v}$ 
$\mathrm{NaCl})$ to remove non-adhering cells. Each disk material was then transferred to a sterile tube containing $1 \mathrm{ml}$ of saline solution and vortexed for $5 \mathrm{~min}$ to ensure detachment of bacteria adherent to the discs surfaces. After vortexing, the cell suspensions were tenfold serially diluted in sterile saline and aliquots $(10 \mu \mathrm{l})$ were surface cultured on blood agar plates, followed by incubation at $37^{\circ} \mathrm{C}$ for $24 \mathrm{~h}$ for determination of viable cell count as colony forming units per milliliter $(\mathrm{CFU} / \mathrm{mL})[29]$.

\subsubsection{Scanning Electron Microscopy (SEM)}

The samples of disk materials were washed with phosphate buffered saline (PBS) and fixed in solution of $4 \% \mathrm{v} / \mathrm{v}$ paraformaldehyde with $1 \%$ glutaraldehyde in PBS for $1 \mathrm{~h}$ and rinsed with PBS three times for 2 min each. Finally, samples were washed with deionized water thrice for $2 \mathrm{~min}$ each and dehydrated through an ethanol series $(50 \%, 70 \%, 80 \%, 95 \%$, and 100\%) for 15 min each, desiccated, sputter-coated, and visualized by a SEM (JSM-5310LV JEOL, Tokyo, Japan). Photographs of representative areas of the polished surfaces were captured at $3000 \times$ magnifications [30].

\subsection{Statistical Analysis}

The results were statistically analyzed by IBM SPSS Statistics version 15.0 (SPSS Inc., Chicago, IL, USA). Data were presented as means \pm standard deviations $( \pm \mathrm{SD})$ for each group. Analyses of data variables were performed using ANOVA followed by Tukey's high significant difference (HSD) test at p-value $<0.05$. Pearson correlation coefficient (PCC), at two-tailed, was used to evaluate the potential association between surface roughness and bacterial adhesion to the tested surfaces.

\section{Results}

\subsection{Surface Roughness}

Two-way ANOVA showed that both the restorative materials and the finishing/polishing systems have significant effects $(\mathrm{p}<0.05)$ on the surface roughness (Table 3).

The results (Table 4) revealed that the polishing systems significantly ( $\mathrm{p}<$ 0.05 ) influenced the surface roughness of different restorative materials. In this context, the Mylar strip showed the smoothest surface followed by PoGo, and the roughest surface was recorded for Sof-lex. On the contrary, different resin composites (FiltekZ350 XT, FiltekZ350 XT, and Tetric N Ceram) had no statistically significant $(\mathrm{p}>0.05)$ influence on the surface roughness and this can be attributed to the existence of polishing systems.

The two dimensional microphotographs of resin composites surfaces (FiltekZ350 XT, FiltekZ350 XT, and Tetric N Ceram) polished with different systems (Mylar strip, Pogo one step, and Sof-lex multi-step) are shown in Figure 1. 
Table 3. Two way ANOVA test results of surface roughness means (nm) among the tested restorative materials and different finishing/polishing systems.

\begin{tabular}{cccccc}
\hline Source & $\begin{array}{c}\text { Type III } \\
\text { Sum of } \\
\text { Squares }\end{array}$ & df & $\begin{array}{c}\text { Mean } \\
\text { Square }\end{array}$ & F & Significance \\
\hline Corrected model & $35187.1^{*}$ & 8 & 4398.3 & 156.7 & 0.000 \\
Intercept & 3323803.0 & 1 & 3323803.0 & 118481.9 & 0.000 \\
restoration & 619.4 & 2 & 309.7 & 11.0 & 0.000 \\
finishing & 33770.3 & 2 & 16885.1 & 601.8 & 0.000 \\
restoration finishing & 797.3 & 4 & 199.3 & 7.1 & 0.000 \\
Error & 2272.3 & 81 & 28.0 & & \\
Total & 3361262.5 & 90 & & & \\
Corrected Total & 37459.4 & 89 & & & \\
\hline
\end{tabular}

${ }^{\star} R^{2}=0.939$ (Adjusted $R^{2}=0.933$ ).

Table 4. Post hoc Tukey's test results of surface roughness of the tested restorative materials with different finishing/polishing systems.

\begin{tabular}{cccc}
\hline \multirow{2}{*}{ Polishing system } & \multicolumn{3}{c}{ Surface roughness of restorative material (nm) } \\
\cline { 2 - 4 } & Filtek Z350 XT & Filtek Bulk Fill & Tetric N Ceram \\
\hline Mylar strip & $161.07 \pm 6.82^{\mathrm{a}}$ & $162.08 \pm 6.82^{\mathrm{a}}$ & $164.19 \pm 6.82^{\mathrm{a}}$ \\
Pogo one step & $188.33 \pm 6.03^{\mathrm{b}}$ & $190.41 \pm 6.03^{\mathrm{b}}$ & $191.42 \pm 6.03^{\mathrm{b}}$ \\
$\begin{array}{c}\text { Sof-lex } \\
\text { multi-step }\end{array}$ & $215.87 \pm 3.876^{\mathrm{c}}$ & $217.89 \pm 3.87^{\mathrm{c}}$ & $217.88 \pm 3.87^{\mathrm{c}}$ \\
\hline
\end{tabular}

Each value represents mean $( \pm S D)$ and values with different superscript letters a, b, c indicate statistically significant difference in surface roughness.

\subsection{Bacterial Adhesion}

The results of two-way ANOVA test revealed that types of polishing systems significantly $(\mathrm{p}<0.05)$ influence the bacterial adhesion (Table 5).

The results demonstrated that adhesion $S$. mutans to Filtek Z350 XT varied significantly $(\mathrm{p}<0.05)$ between different finishing/polishing systems. The highest bacterial adhesion was observed with Sof-lex multi-step and the lowest one was observed with Mylarstrip. On the other hand, different types of restorative materials (FiltekZ350 XT, FiltekZ350 XT, and Tetric N Ceram) showed non-significant ( $\mathrm{p}>0.05$ ) effect on bacterial adhesion (Table 6).

Adhesion of $S$. mutans ATCC 25175, as captured by SEM, to resin composites surfaces (FiltekZ350 XT, FiltekZ350 XT, and Tetric N Ceram) polished with different systems (Mylar strip, Pogo one step, and Sof-lex multi-step) are shown in Figure 2. Pearson correlation test revealed a statistically significant $(\mathrm{p}<0.001)$ and strong association ( $\mathrm{PCC}=0.943$ ) between surface roughness and bacterial adhesion to the tested surfaces. 

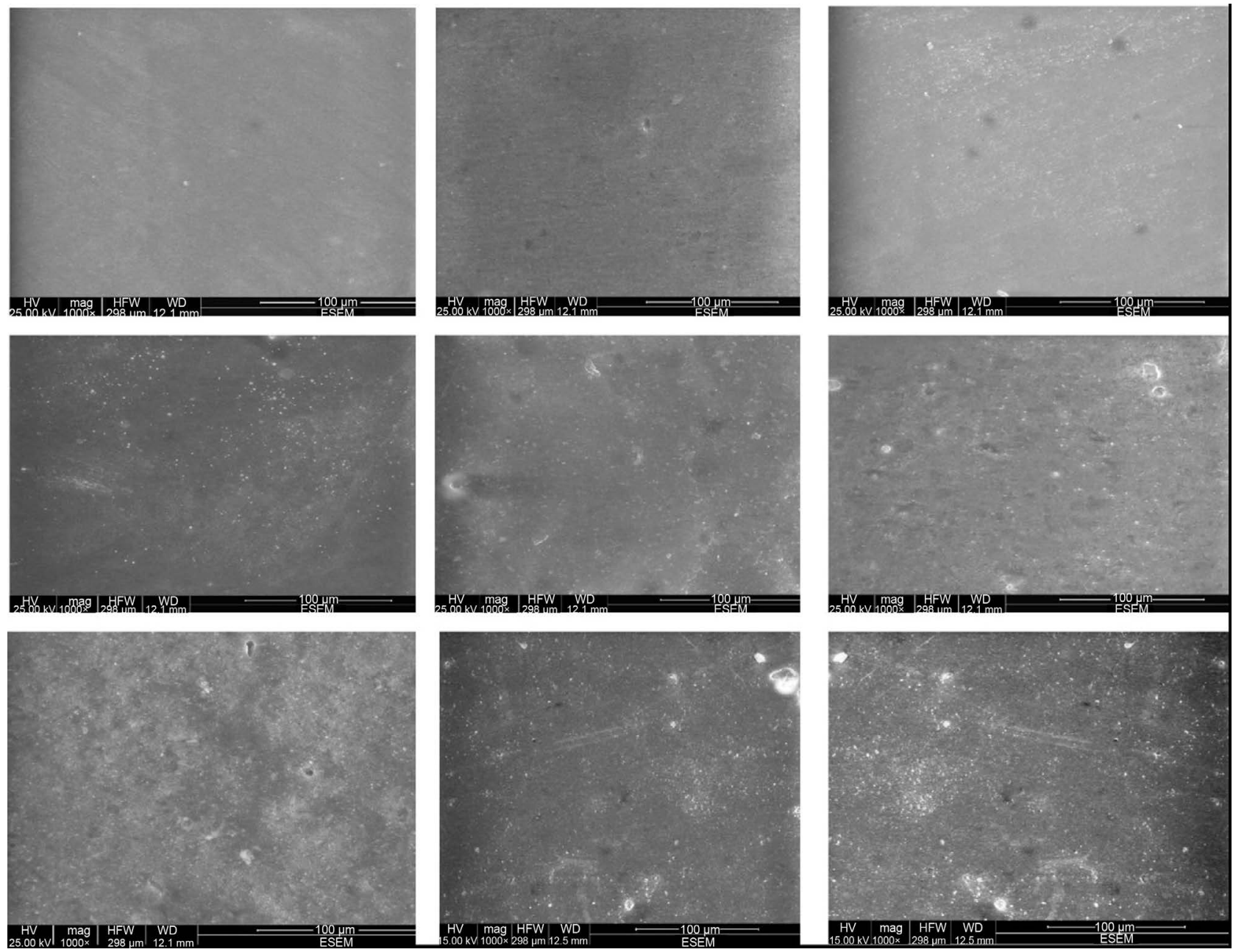

Figure 1. Two dimensional photomicrograph of resin composites surfaces polished with different polishing systems: (A) FiltekZ350 XT with Mylar strip, (B) Filtek Bulk-fill with Mylar strip, (C) Tetric N Ceram with Mylar strip, (D) FiltekZ350 XT with Pogo one step, (E) Filtek Bulk-fill with Pogo one step, (F) Tetric N Ceram with Pogo one step, (G) FiltekZ350 XT with Sof-lex multi-step, (H) Filtek Bulk-fill with Sof-lex multi-step, (I) Tetric N Ceram with Sof-lex multi-step.

\section{Discussion}

Bulk fill restorative materials have been developed to enable dentists to efficiently reduce placement time and effort. Little information is available about the performance of this new bulk fill materials. Successful esthetic restoration should mimic the surface smoothness and gloss of human enamel. The effectiveness of finishing and polishing procedures on esthetic restorative materials is a crucial factor in restorative treatment. Accordingly, smoother surfaces are generally obtained by curing the materials against Mylar matrix strips. Unfortunately, this procedure is often clinically insufficient because post-curing finishing procedures have to be performed to remove excess material, obtain the correct anatomical form, and polish the surfaces [18]. Surface roughness in this study was evaluated by ESEM which provides both qualitative \& quantitative data of the surface [28]. In accordance with the published data [31], the results of this study revealed that the surface roughness of the tried restorative materials 

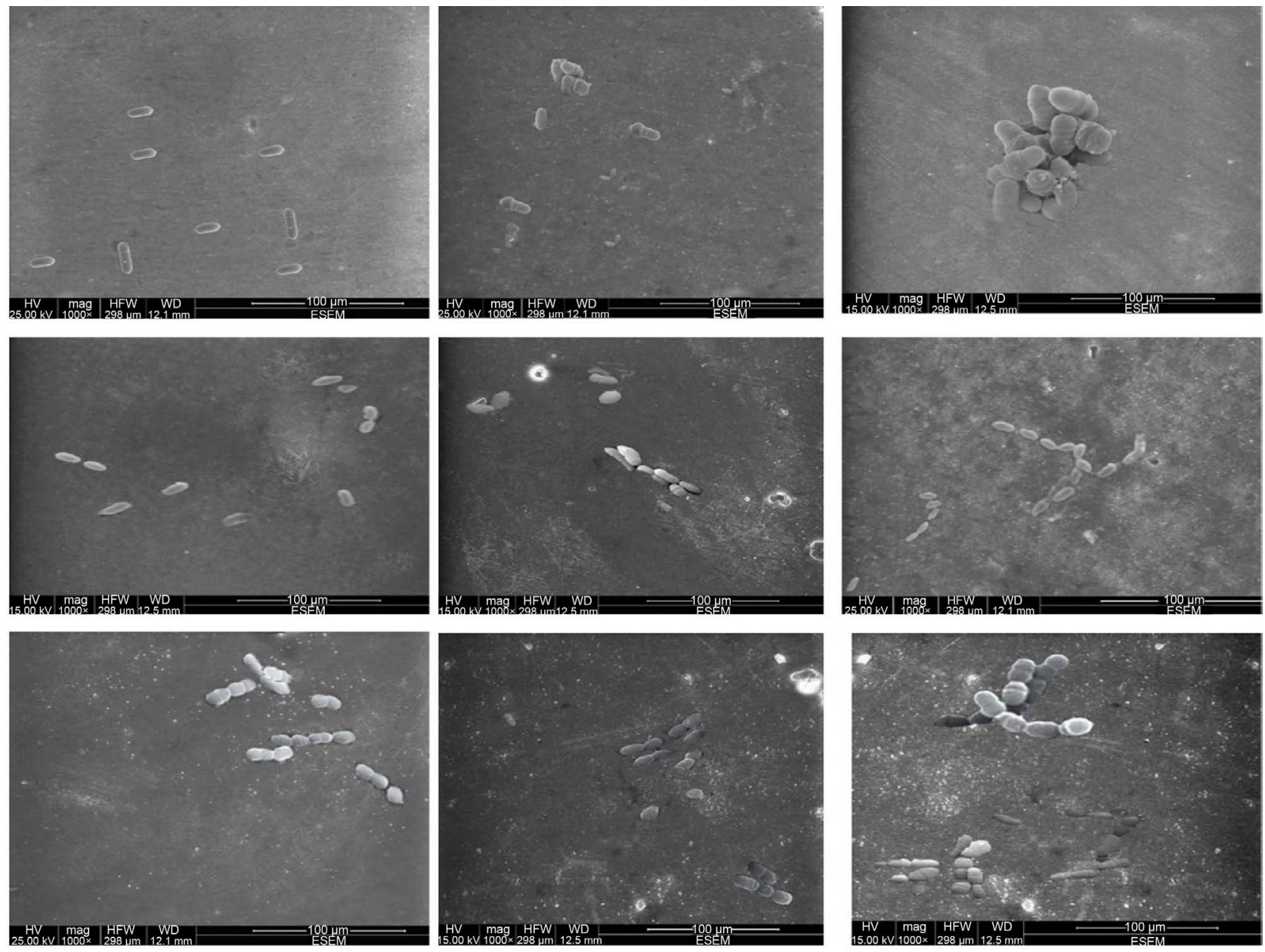

Figure 2. Two dimensional SEM micrographs of Streptococcus mutans ATCC 25,175 adhesion to the surfaces of resin composites polished with different polishing systems: (A) FiltekZ350 XT with Mylar strip, (B) FiltekZ350 XT with Pogo one step, (C) FiltekZ350 XT with Sof-lex multi-step, (D) Filtek Bulk-fill with Mylar strip, (E) Filtek Bulk-fill with Pogo one step, (F) Filtek Bulk-fill with Sof-lex multi-step, (G) Tetric N Ceram with Mylar strip, (H) Tetric N Ceram with Pogo one step, (I) Tetric N Ceram with Sof-lex multi-step.

have effect on the polishing systems with statistical significance.

In the present study, the lowest roughness values were recorded with the Mylar strip samples. The smoothest surface next to Mylar strip was obtained with one-step Pogo polishing system followed by multi-step Sof-lex polishing system. These findings are in agreement with that of Costa et al. [32], who reported that one-step system provides the highest gloss values. Conversely, the outcome of this study contradicts with that of Nasoohi et al. [33], who reported that finishing and polishing techniques need sequential usage of instrumentation with progressively smaller grained abrasives to finallyatta in the anticipated glossy surface. In this study, Sof-Lex multi-step finishing system revealed rougher surfaces than PoGo one-step finishing system with all tested composites.

The results of the present study revealed that the surface roughness of all tested restorative materials were significantly influenced by the type of finishing/polishing system and Mylar strip produced the smoothest surface and that 
Table 5. Two way ANOVA test results of bacterial adhesion means among tested restorative materials and different finishing/polishing systems.

\begin{tabular}{cccccc}
\hline Source & $\begin{array}{c}\text { Type III Sum } \\
\text { of Squares }\end{array}$ & df & $\begin{array}{c}\text { Mean } \\
\text { Square }\end{array}$ & F & Significance \\
\hline Corrected model & $106012.8^{*}$ & 8 & 13251.6 & 255.6 & 0.000 \\
Intercept & 3537870.4 & 1 & 3537870.4 & 68249.8 & 0.000 \\
restoration & 785.0 & 2 & 392.5 & 7.5 & 0.001 \\
finishing & 103731.8 & 2 & 51865.9 & 1000.5 & 0.000 \\
restoration finishing & 1496.0 & 4 & 374.0 & 7.2 & 0.000 \\
Error & 4198.8 & 81 & 51.8 & & \\
Total & 3648082.0 & 90 & & & \\
Corrected total & 110211.6 & 89 & & & \\
\hline
\end{tabular}

${ }^{\star} R^{2}=0.939$ (Adjusted $R^{2}=0.933$ ).

Table 6. Post hoc Tukey's test results of Streptococcus mutans ATCC 25,175 adhesion to the tested restorative materials with different finishing/polishing systems.

\begin{tabular}{cccc}
\hline \multirow{2}{*}{ Polishing system } & \multicolumn{3}{c}{ Bacterial adhesion to restorative material $\left(\mathrm{CFU} \times 10^{3} / \mathrm{mL}\right)$} \\
\cline { 2 - 4 } & Filtek Z350 XT & Filtek Bulk Fill & Tetric N Ceram \\
\hline Mylar strip & $156.40 \pm 6.50^{\mathrm{a}}$ & $158.40 \pm 6.50^{\mathrm{a}}$ & $159.40 \pm 6.50^{\mathrm{a}}$ \\
Pogo one step & $199.40 \pm 5.31^{\mathrm{b}}$ & $201.40 \pm 5.31^{\mathrm{b}}$ & $202.40 \pm 5.31^{\mathrm{b}}$ \\
Sof-lex multi-step & $226.50 \pm 4.00^{\mathrm{c}}$ & $228.50 \pm 4.00^{\mathrm{c}}$ & $229.50 \pm 4.00^{\mathrm{c}}$ \\
\hline
\end{tabular}

Each value represents mean $( \pm \mathrm{SD})$ and values with different superscript letters a, b, c indicate statistically significant difference in bacterial adhesion.

may be due to its highly lustrous feature, which cannot be created with other polishing system, and this findings are consistent with some previous studies [34] [35]. Both Filtek Z350XT and Filtek Bulk-fill have nearly the same surface roughness which may be attributed to the similarity of the filler particle size (pure nano-filled) as compared to Tetric $\mathrm{N}$ Ceram which has higher nano-hybrid size as described previously [36] [37].

Cariopathogenic biofilms on tooth surfaces or artificial dental substrata are primarily formed by initial adhesion of specific oral bacteria to such surfaces. Within the complex process of biofilm development, $S$. mutans is primarily responsible for the initiation of tooth decay as well as for the progression of an established lesion[38].The selection of $S$. mutans for adhesion assay in this study was based on the fact that $S$. mutans is considered as a major etiological agent of dental caries [39] [40]. In this study, the adhered cells were removed for subsequent quantification after $4 \mathrm{~h}$. This time of exposure was chosen because initial steps of biofilm development in the oral cavity normally occur within $4 \mathrm{~h}$ [41] [42].

The results of the present study indicated that bacterial adhesion differs significantly between various polishing systems, where Mylarstrip produced the lowest bacterial adhesion, followed by PoGo, and the highest value recorded with Sof-lex. This finding maybe attributed to the variable polishing capacity 
and the surface roughness of these systems which significantly influence the bacterial adhesion to the substrata as describe previously [43] [44] [45]. Bacterial adhesion is governed by non-specific interactions (physico-chemical interactions) and specific (ligand-receptor like interactions). Non-Specific interactions involve van der Waals, acid-base, and electrostatic interactions. The integration of such interactions plays a fundamental role in the initial bacterial adhesion as well as in biofilm formation [46].

In the current study, Pearson correlation test indicated a strongly positive correlation $(\mathrm{PCC}=0.943)$ between surface roughness and $S$. mutans adhesion to the tested surfaces. In accordance with our results, some investigators have mentioned potential correlations between surface roughness and bacterial adhesion [47] [48]. Similarly, it has been reported that $S$. aureus adhesion was strongly correlated to the surface roughness [49]. Furthermore, qualitative and quantitative adhesion analyses on different surfaces demonstrated significant aggregation of bacterial cells on untreated surfaces than on electro polished smooth surfaces [50]. Conversely, Eick et al. [51] disagreed with this relationship and reported that nocorrelation was observed between surface roughness and the number of colony forming units (CFU) of $S$. mutans in their study.

\section{Conclusion}

The current study revealed a strong association between surface roughness and $S$. mutans adhesion to the tested surfaces. Irrespective of the restorative material, Mylar polishing system presented the smoothest surface and the least bacterial adhesion as compared to Sof-Lex multi-step and Pogo one step polishing systems. Consequently, Mylar polishing system would be more recommended for clinical application.

\section{Conflicts of Interest}

The authors declare no conflict of interest.

\section{Funding Statement}

This research has not received any specific grants from funding agencies in the public, commercial, or nonprofit sectors.

\section{References}

[1] Filoche, S., Wong, L. and Sissons, C. (2010) Oral Biofilms: Emerging Concepts in Microbial Ecology. Journal of Dental Research, 89, 8-18.

https://doi.org/10.1177/0022034509351812

[2] Ono, M., Nikaido, T., Ikeda, M., Imai, S., Hanada, N., Tagami, J., et al. (2007) Surface Properties of Resin Composite Materials Relative to Biofilm Formation. Dental Materials Journal, 26, 613-622. https://doi.org/10.4012/dmj.26.613

[3] Hojo, K., Nagaoka, S., Ohshima, T. and Maeda, N. (2009) Bacterial Interactions in Dental Biofilm Development. Journal of Dental Research, 88, 982-990. https://doi.org/10.1177/0022034509346811 
[4] Teughels, W., Van Assche, N., Sliepen, I. and Quirynen, M. (2006) Effect of Material Characteristics and/or Surface Topography on Biofilm Development. Clinical Oral Implants Research, 17, 68-81. https://doi.org/10.1111/j.1600-0501.2006.01353.x

[5] Subramani, K., Jung, R.E., Molenberg, A. and Hämmerle, C.H. (2009) Biofilm on Dental Implants: A Review of the Literature. International Journal of Oral \& Maxillofacial Implants, 24, 616-626.

[6] Lutz, F., Krejci, I. and Barbakow, F. (1991) Quality and Durability of Marginal Adaptation in Bonded Composite Restorations. Dental Materials, 7, 107-113. https://doi.org/10.1016/0109-5641(91)90055-4

[7] Dauvillier, B.S., Aarnts, M.P. and Feilzer, A.J. (2000) Developments in Shrinkage Control of Adhesive Restoratives. Journal of Esthetic and Restorative Dentistry, 12, 291-299. https://doi.org/10.1111/j.1708-8240.2000.tb00238.x

[8] Versluis, A., Douglas, W., Cross, M. and Sakaguchi, R. (1996) Does an Incremental Filling Technique Reduce Polymerization Shrinkage Stresses? Journal of Dental Research, 75, 871-878. https://doi.org/10.1177/00220345960750030301

[9] Kwon, Y., Ferracane, J. and Lee, I.-B. (2012) Effect of Layering Methods, Composite Type, and Flowable Liner on the Polymerization Shrinkage Stress of Light Cured Composites. Dental Materials, 2, 801-809.

https://doi.org/10.1016/j.dental.2012.04.028

[10] Tjan, A.H., Bergh, B.H. and Lidner, C. (1992) Effect of Various Incremental Techniques on the Marginal Adaptation of Class II Composite Resin Restorations. Journal of Prosthetic Dentistry, 67, 62-66. https://doi.org/10.1016/0022-3913(92)90051-B

[11] Czasch, P. and Ilie, N. (2013) In Vitro Comparison of Mechanical Properties and Degree of Cure of Bulk Fill Composites. Clinical Oral Investigations, 17, 227-235. https://doi.org/10.1007/s00784-012-0702-8

[12] Bollenl, C.M., Lambrechts, P. and Quirynen, M. (1997) Comparison of Surface Roughness of Oral Hard Materials to the Threshold Surface Roughness for Bacterial Plaque Retention: A Review of the Literature. Dental Materials, 13, 258-269. https://doi.org/10.1016/S0109-5641(97)80038-3

[13] Cilli, R., de Mattos, M.C.R., Honorio, H.M., Rios, D., de Araujo, P.A. and Prakki, A. (2009) The Role of Surface Sealants in the Roughness of Composites after a Simulated Toothbrushing Test. Journal of Dentistry, 37, 970-977. https://doi.org/10.1016/j.jdent.2009.08.002

[14] Bürgers, R., Cariaga, T., Müller, R., Rosentritt, M., Reischl, U., Handel, G., et al. (2009) Effects of Aging on Surface Properties and Adhesion of Streptococcus mutans on Various Fissure Sealants. Clinical Oral Investigations, 13, 419-426. https://doi.org/10.1007/s00784-009-0256-6

[15] Paravina, R., Roeder, L., Lu, H., Vogel, K. and Powers, J. (2004) Effect of Finishing and Polishing Procedures on Surface Roughness, Gloss and Color of Resin-Based Composites. American Journal of Dentistry, 17, 262-266.

[16] St-Georges, A., Bolla, M., Fortin, D., Muller-Bolla, M., Thompson, J. and Stamatiades, P. (2005) Surface Finish Produced on Three Resin Composites by New Polishing Systems. Operative Dentistry, 30, 593-597.

[17] Yap, A., Ng, J., Yap, S. and Teo, C. (2004) Surface Finish of Resin-Modified and Highly Viscous Glass Ionomer Cements Produced by New One-Step Systems. Operative Dentistry, 29, 87-91.

[18] de Souza Ferreira, R., Carpena Lopes, G. and Narcisco Baratieri, L. (2004) Direct 
Posterior Resin Composite Restorations: Considerations on Finishing/Polishing. Clinical Procedures. Quintessence International, 35, 359-366.

[19] Li, J., Helmerhorst, E., Leone, C.W., Troxler, R., Yaskell, T., Haffajee, A., et al. (2004) Identification of Early Microbial Colonizers in Human Dental Biofilm. Journal of Applied Microbiology, 97, 1311-1318. https://doi.org/10.1111/j.1365-2672.2004.02420.x

[20] Stewart, P.S. and Franklin, M.J. (2008) Physiological Heterogeneity in Biofilms. Nature Reviews Microbiology, 6, 199. https://doi.org/10.1038/nrmicro1838

[21] Pihlstrom, B.L., Michalowicz, B.S. and Johnson, N.W. (2005) Periodontal Diseases. The Lancet, 366, 1809-1820. https://doi.org/10.1016/S0140-6736(05)67728-8

[22] Bernardo, M., Luis, H., Martin, M.D., Leroux, B.G., Rue, T., Leitão, J., et al. (2007) Survival and Reasons for Failure of Amalgam versus Composite Posterior Restorations Placed in a Randomized Clinical Trial. The Journal of the American Dental Association, 138, 775-783. https://doi.org/10.14219/jada.archive.2007.0265

[23] Zijnge, V., van Leeuwen, M.B.M., Degener, J.E., Abbas, F., Thurnheer, T., Gmür, R., et al. (2010) Oral Biofilm Architecture on Natural Teeth. PLoS ONE, 5, e9321. https://doi.org/10.1371/journal.pone.0009321

[24] Guggenheim, B., Guggenheim, M., Gmür, R., Giertsen, E. and Thurnheer, T. (2004) Application of the Zürich Biofilm Model to Problems of Cariology. Caries Research, 38, 212-222. https://doi.org/10.1159/000077757

[25] Katsikogianni, M. and Missirlis, Y. (2004) Concise Review of Mechanisms of Bacterial Adhesion to Biomaterials and of Techniques Used in Estimating Bacteria-Material Interactions. European Cells \& Materials, 8, 37-57. https://doi.org/10.22203/eCM.v008a05

[26] Sungurtekin-Ekci, E., Ozdemir-Ozenen, D., Duman, S., Acuner, I.C. and Sandalli, N. (2015) Antibacterial Surface Properties of Various Fluoride-Releasing Restorative Materials in Vitro. Journal of Applied Biomaterials \& Functional Materials, 13, 169-173. https://doi.org/10.5301/jabfm.5000212

[27] Moshaverinia, A., Roohpour, N., Chee, W.W. and Schricker, S.R. (2011) A Review of Powder Modifications in Conventional Glass-Ionomer Dental Cements. Journal of Materials Chemistry, 21, 1319-1328. https://doi.org/10.1039/C0JM02309D

[28] Hafez, R., Ahmed, D., Yousry, M., El-Badrawy, W. and El-Mowafy, O. (2010) Effect of In-Office Bleaching on Color and Surface Roughness of Composite Restoratives. European Journal of Dentistry, 4, 118.

[29] Vyavahare, N.G.S., Raghavendra, S.S. and Kazi, M.M. (2014) Effect of Finishing and Polishing Procedures on Biofilm Adhesion to Composite Surfaces: An ex Vivo Study. JDAS, 3, 70-73.

[30] Kim, D.H. and Kwon, T.-Y. (2017) In Vitro Study of Streptococcus Mutans Adhesion on Composite Resin Coated with Three Surface Sealants. Restorative Dentistry \& Endodontics, 42, 39-47. https://doi.org/10.5395/rde.2017.42.1.39

[31] Aytac, F., Karaarslan, E.S., Agaccioglu, M., Tastan, E., Buldur, M. and Kuyucu, E. (2016) Effects of Novel Finishing and Polishing Systems on Surface Roughness and Morphology of Nanocomposites. Journal of Esthetic and Restorative Dentistry, 28, 247-261. https://doi.org/10.1111/jerd.12215

[32] Costa, J.D., Ferracane, J., Paravina, R.D., Mazur, R.F. and Roeder, L. (2007) The Effect of Different Polishing Systems on Surface Roughness and Gloss of Various Resin Composites. Journal of Esthetic and Restorative Dentistry, 19, 214-224. https://doi.org/10.1111/j.1708-8240.2007.00104.x 
[33] Nasoohi, N., Hoorizad, M. and Tabatabaei, S.F. (2017) Effects of Wet and Dry Finishing and Polishing on Surface Roughness and Microhardness of Composite Resins. Journal of Dentistry, 14, 69.

[34] Zimmerli, B., Lussi, A. and Flury, S. (2011) Operator Variability Using Different Polishing Methods and Surface Geometry of a Nanohybrid Composite. Operative Dentistry, 36, 52-59. https://doi.org/10.2341/10-096-LR1

[35] Turssi, C.P., Ferracane, J.L. and Serra, M.C. (2005) Abrasive Wear of Resin Composites as Related to Finishing and Polishing Procedures. Dental Materials, 21, 641-648. https://doi.org/10.1016/j.dental.2004.10.011

[36] Ferracane, J. (1994) Elution of Leachable Components from Composites. Journal of Oral Rehabilitation, 21, 441-452. https://doi.org/10.1111/j.1365-2842.1994.tb01158.x

[37] Jung, M., Eichelberger, K. and Klimek, J. (2007) Surface Geometry of Four Nanofiller and One Hybrid Composite after One-Step and Multiple-Step Polishing. Operative Dentistry, 32, 347-355. https://doi.org/10.2341/06-101

[38] Brambilla, E., Cagetti, M.G., Gagliani, M., Fadini, L., García-Godoy, F. and Strohmenger, L. (2005) Influence of Different Adhesive Restorative Materials on Mutans Streptococci Colonization. American Journal of Dentistry, 18, 173.

[39] Kolenbrander, P.E., Palmer, R.J., Rickard, A.H., Jakubovics, N.S., Chalmers, N.I. and Diaz, P.I. (2000) Bacterial Interactions and Successions during Plaque Development. Periodontology, 42, 47-79. https://doi.org/10.1111/j.1600-0757.2006.00187.x

[40] Ozel, G.S., Guneser, M.B., Inan, O. and Eldeniz, A.U. (2017) Evaluation of C. albicans and $S$. mutans Adherence on Different Provisional Crown Materials. The Journal of Advanced Prosthodontics, 9, 335-340. https://doi.org/10.4047/jap.2017.9.5.335

[41] Poggio, C., Arciola, C.R., Rosti, F., Scribante, A., Saino, E. and Visai, L. (2009) Adhesion of Streptococcus mutans to Different Restorative Materials. The International Journal of Artificial Organs, 32, 671-677. https://doi.org/10.1177/039139880903200917

[42] Montanaro, L., Campoccia, D., Rizzi, S., Donati, M.E., Breschi, L., Prati, C., et al. (2004) Evaluation of Bacterial Adhesion of Streptococcus mutans on Dental Restorative Materials. Biomaterials, 25, 4457-4463. https://doi.org/10.1016/j.biomaterials.2003.11.031

[43] Kawai, K., Urano, M. and Ebisu, S. (2000) Effect of Surface Roughness of Porcelain on Adhesion of Bacteria and Their Synthesizing Glucans. Journal of Prosthetic Dentistry, 83, 664-667. https://doi.org/10.1067/mpr.2000.107442

[44] Saku, S., Kotake, H., Scougall-Vilchis, R.J., Ohashi, S., Hotta, M., Horiuchi, S., et al. (2010) Antibacterial Activity of Composite Resin with Glass-Ionomer Filler Particles. Dental Materials Journal, 29, 193-198. https://doi.org/10.4012/dmj.2009-050

[45] Meier, R., Hauser-Gerspach, I., Lüthy, H. and Meyer, J. (2008) Adhesion of Oral Streptococci to All-Ceramics Dental Restorative Materials in Vitro. Journal of Materials Science: Materials in Medicine, 19, 3249. https://doi.org/10.1007/s10856-008-3457-7

[46] Hsu, L.C., Fang, J., Borca-Tasciuc, D.A., Worobo, R.W. and Moraru, C.I. (2013) Effect of Micro- and Nanoscale Topography on the Adhesion of Bacterial Cells to Solid Surfaces. Applied and Environmental Microbiology, 79, 2703-2712. https://doi.org/10.1128/AEM.03436-12

[47] Rodríguez-Hernández, A.G., Juárez, A., Engel, E. and Gil, F. (2011) Streptococcus 
sanguinis Adhesion on Titanium Rough Surfaces: Effect of Shot-Blasting Particles. Journal of Materials Science: Materials in Medicine, 22, 1913-1922. https://doi.org/10.1007/s10856-011-4366-8

[48] Martínez-Gomis, J., Bizar, J., Anglada, J.M., Samsó, J. and Peraire, M. (2003) Comparative Evaluation of Four Finishing Systems on One Ceramic Surface. International Journal of Prosthodontics, 16, 74-77.

[49] Harris, L.G., Meredith, D.O., Eschbach, L. and Richards, R.G. (2007) Staphylococcus aureus Adhesion to Standard Micro-Rough and Electropolished Implant Materials. Journal of Materials Science: Materials in Medicine, 18, 1151-1156. https://doi.org/10.1007/s10856-007-0143-0

[50] Wu, S., Altenried, S., Zogg, A., Zuber, F., Maniura-Weber, K. and Ren, Q. (2018) Role of the Surface Nanoscale Roughness of Stainless Steel on Bacterial Adhesion and Microcolony Formation. ACS Omega, 3, 6456-6464.

https://doi.org/10.1021/acsomega.8b00769

[51] Eick, S., Glockmann, E., Brandl, B. and Pfister, W. (2004) Adherence of Streptococcus mutans to Various Restorative Materials in a Continuous Flow System. Journal of Oral Rehabilitation, 31, 278-285.

https://doi.org/10.1046/j.0305-182X.2003.01233.x 